石油技術協会誌 第 82 巻 第 1 号 （平成 29 年 1 月） $73 \sim 84$ 頁 Journal of the Japanese Association for Petroleum Technology Vol. 82, No. 1 (Jan., 2017) pp. 74 84

\begin{tabular}{c}
\hline 論 説 \\
Original Article
\end{tabular}

\title{
Effect of Emulsification Process Conditions on the Properties of Water-in-Bitumen Emulsion
}

\author{
Alade Olalekan. S. ${ }^{*, *}$, Kyuro Sasaki ${ }^{*,}$, Yuichi Sugai ${ }^{*}$, Bayo Ademodi ${ }^{* *}$ \\ Jumpei Kumasaka* and Ryo Ueda ${ }^{* * *}$
}

(Received July 8, 2016 ; accepted January 26, 2017)

\begin{abstract}
Steam or hot water injection into the bitumen reservoir leads to the formation of water-in-bitumen emulsions which exhibit higher viscosity compared to the original bitumen; and thereby affects production flow. The understanding of the effect of formation process conditions on the nature of this emulsion could assist in production improvement, design and simulation of post-production separation system. In this work, water was dispersed in bitumen phase at different temperatures $\left(50-180^{\circ} \mathrm{C}\right)$ and mixing speeds $\left(11.7-23.3 \mathrm{~s}^{-1}\right)$. Emulsification properties such as percentage emulsification (extent of water dispersion into the bitumen), and the particle size of emulsion were analyzed to evaluate the effects of the process conditions. Ultimately, correlations have been presented to predict emulsion properties from the process conditions.
\end{abstract}

Keywords : bitumen, emulsification, formation temperature, mixing speed, particle size

\section{Introduction}

Emulsion is a popular term which is frequently encountered in the petroleum industries (Badolato et al., 2008; Wong et al., 2015). The popularly reported types of emulsion encountered in the petroleum industry include oil-in-water $(\mathrm{O} / \mathrm{W})$, waterin-oil (W/O), and their complex forms (Martínez-Palou et $a l ., 2011)$. Oil-in-water (O/W) emulsion is a liquid-liquid dispersed system in which the particles of oil are dispersed in continuous water phase. On the other hand, water-inoil (W/O) emulsion contains water particles dispersed in a continuous oil phase.

It generally holds that emulsion is formed through the action of a surface active agent (known as surfactant) assisted by mixing force in destabilizing the interfacial tension between the two immiscible liquids. Emulsion has similarly been viewed as either the desired result of a mechanical process or the spontaneous result of favorable conditions of formation (Clausse et al., 2005). Thus, emulsification process

* 九州大学大学院工学研究院地球資源システム工学部門 Resources Production and Safety Engineering Laboratory, Department of Earth Resources Engineering, Kyushu University, Fukuoka, Japan

**オバフェミ・アウォウォ大学化学工学科石油および石油化学工学研究 室 Petroleum and Petrochemical Engineering Laboratory, Department of Chemical Engineering, Obafemi Awolowo University, Ile-Ife, Osun State, Nigeria

*** 石油資源開発株式会社 技術研究所 Research Center, Japan Petroleum Exploration, Co., Ltd.

† Corresponding author : E-Mail : krsasaki@mine.kyushu-u.ac.jp needs an energy input, which is traditionally achieved through shaking, stirring or some other kind of intensive dynamic and/or static mixing processes (Fradette et al., 2007; Hassan et al., 2010) . Furthermore, as a result of mixing force and the presence of the natural surfactants (asphaltene and resin) and clay, an undesirable water-in-oil emulsion is mostly formed during crude oil production (Antes et al., 2015; Wong et al., 2015). Emulsification, during petroleum production, occurs due to contact of two immiscible liquids, presence of surface active components, and availability of sufficient turbulence or mixing energy to cause dispersion (Wong et al., 2015; Wen et al., 2016).

Specifically, the in situ Thermal EOR (TEOR) methods including steam assisted gravity drainage (SAGD), cyclic steam stimulation (CSS) or Huff and Puff method, steam flooding, and their hybrids involves injection of steam (and additives including solvents and surfactants) into the heavy oil reservoir for the purpose of reducing viscosity and increasing mobility (Bennion et al., 1993; Yamazaki et al., 1994; AlBahlani and Babadagli, 2009). During these processes, the thermal energy possessed by the steam is transferred to the oil in situ. Then, following condensation, oil and water flow through the pores of the sand grains which produces shearing force. Thus, as illustrated in Fig. 1, emulsification occurs through the reduction of interfacial tension between the liquid and oil (and under the shearing effect of flow); thereby causes dispersion of water particles into the oil phase stabilized by 


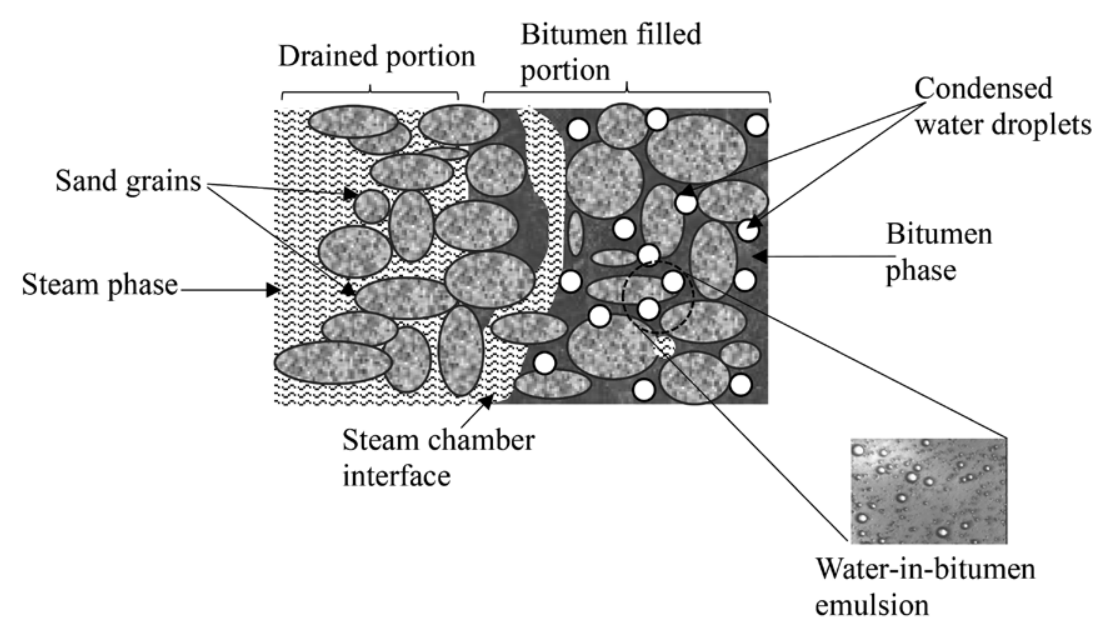

Fig. 1 Illustration of in situ emulsification and formation of water-in-bitumen emulsion during steam assisted recovery pr ${ }^{\circ} \mathrm{C}$ ess Source: adapted from Mohammadzadeh and Chatzis (2010)

the natural emulsion stabilizers (asphaltene, resin, and clay) present in the oil (Alade et al., 2016a).

SAGD is one of the most popular TEOR methods which has been successfully established in the recovery of bitumen from the huge (estimated over 175 billion barrels of proven reserves) of Canadian oil sand resource (Takahasi and Ogino, 2005; Wada, 2006; Al-Bahlani and Babadagli, 2009; Kato et al., 2013). As earlier described, the produced bitumen through SAGD is usually in form of water-inbitumen emulsion which could exhibit remarkable increase in apparent viscosity and non-Newtonian behavior compared to the original bitumen (Bennion et al., 1993; Al-Bahlani and Babadagli, 2009). Therefore, effect of in situ emulsification on the performance of SAGD process had been the focus of some previous investigations (Chung and Butler, 1987; Chun and Butler, 1989; Sasaki et al., 2001; Sasaki et al., 2002; Al-Bahlani and Babadagli, 2009; Kumasaka et al., 2016). In addition, studies on the bitumen emulsification as a result of steam quality, pressure and reservoir geometry have been reported (Chung and Butler, 1987; Chun and Butler, 1989; Al-Bahlani and Babadagli, 2009). However, investigation on the effects of emulsification conditions (such as formation temperature, and mixing speed) that lead to the formation of emulsion downhole has not received significant attention. Prior to this study, process parameter including temperature and mixing speed have been linked with the particle size of bitumen-in-water emulsion which was formed in the presence of chemical surfactant using in-line static mixers (Gingras, et al., 2005). Similarly, effects of process parameters was investigated on the characteristics of emulsion formed with the light crude (Wen et al., 2016). However, such study as concerned formation of water-in-bitumen emulsion has rarely been reported. Therefore, in this work, the effects of the process conditions on emulsification properties such as the percentage emulsification (extent of water dispersion into the bitumen), and the particle size of emulsion were investigated. This is with the aim of providing quantitative information which can be applied during steam injection operations for bitumen recovery; and post production separation of water-inbitumen emulsion produced.

\section{Materials and methods}

Bitumen samples collected from an oil field in Canada (Oil C) and Nigeria (Oil N) were used in this investigation. The properties of the bitumen samples are presented in Table 1.

\subsection{Bitumen emulsification}

Batch emulsification experiments to generate water-inbitumen emulsions were performed in a micro-reactor vessel with a volume of $50 \mathrm{~mL}$ under controlled high temperature and pressure conditions (MMJ-50, OM Labtech, Tochigi, Japan) with an anchor impeller for agitation (Fig. 2). In a batch emulsification process, $25 \mathrm{~mL}$ of the sample with a bitumen-water ratio of $1: 1\left(C_{B}=50 \% \mathrm{w} / \mathrm{w}\right.$ and $C_{W}=50 \% \mathrm{w} /$ w) was mixed at a formation temperature $\left(T_{f}\right)$ of $50-180{ }^{\circ} \mathrm{C}$ (saturation pressure $=0.03-0.89 \mathrm{MPa}$ ), and mixing speed $\left(N_{i}\right)$ of $11.7-23.3 \mathrm{~s}^{-1}$ for a mixing time $\left(t_{m}\right)$ of $20 \mathrm{~min}$.

Table 1 Physical properties of bitumen samples

\begin{tabular}{lll}
\hline $\begin{array}{l}\text { Property of bitumen } \\
\text { Viscosity }(\mathrm{mPas}) \text { at } 70{ }^{\circ} \mathrm{C}\end{array}$ & $\begin{array}{l}\text { Canadian } \\
(\text { Oil C) }\end{array}$ & $\begin{array}{l}\text { Nigerian } \\
(\text { Oil N) }\end{array}$ \\
S.G $\left(15 / 15{ }^{\circ} \mathrm{C}\right)$ & 1.016 & 7860 \\
Asphaltene content & $13.40 \%$ & $24.80 \%$ \\
\hline
\end{tabular}

Table 2 Experimental conditions

\begin{tabular}{ll}
\hline Parameter & Value \\
\hline Formation temperature $T_{f}\left({ }^{\circ} \mathrm{C}\right)$ & $50-180$ \\
Mixing speed $N_{i}\left(\mathrm{~s}^{-1}\right)$ & $11.7-23.3$ \\
Mixing time $t_{m}(\mathrm{~s})$ & 1200 \\
Bitumen content $C_{B}(\% \mathrm{w} / \mathrm{w})$ & 50 \\
\hline
\end{tabular}




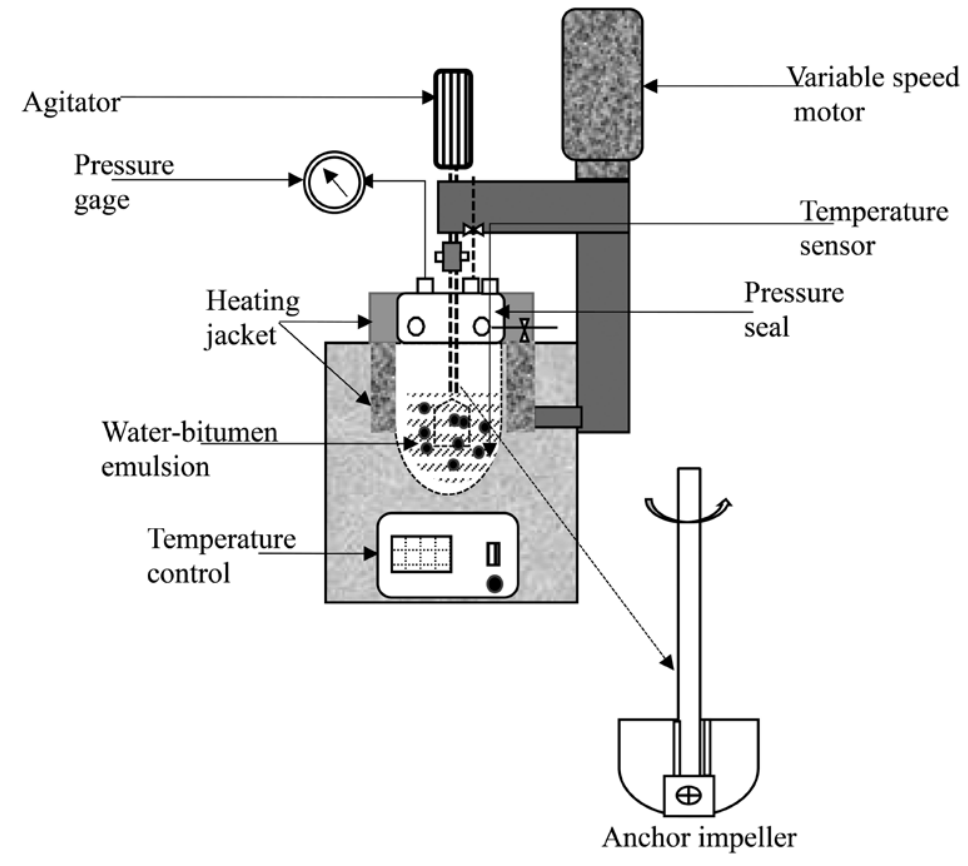

Fig. 2 Sketch of the high pressure and temperature micro-reactor (with anchor impeller)

Experimental conditions are presented in Table 2.

\subsection{Particle size analysis}

The particle size of emulsions were analyzed using optical/ video microscopy method. Detail procedure is available in our previous publication (Alade et al., 2016b). The average diameter of particles of emulsion was estimated using volume mean diameter, $d_{v}$, for a number of droplets $\left(n_{i}\right)$ counted as ith diameter of the droplet $\left(d_{i}\right)$ as given in equation (1):

$$
d_{v}=\frac{\sum\left(n_{i} d_{i}^{4}\right)}{\sum\left(n_{i} d_{i}^{3}\right)}
$$

The particle size distribution was expressed as the lognormal probability density function $f(x)$ :

$$
f(x)=\frac{1}{x \sigma \sqrt{2 \pi}} \exp \left(-\frac{(\ln (x)-\omega)^{2}}{2 \sigma^{2}}\right)
$$

where $x$ is the variable, $\sigma$ is the shape parameter (and is the standard deviation of the log of the distribution), $\omega$ is the mean of the log of the distribution.

\subsection{Viscosity test of original samples of bitumen and water-in-bitumen emulsions}

The viscosity of original bitumen samples were measured at atmospheric pressure and different temperatures $(70-$ $180^{\circ} \mathrm{C}$ ) using the plumbing type viscosity sensor (Cambridge Viscosity, Model SPL372 - see Fig. 3a). The operating principle is simply such that the instrument expresses the dynamic viscosity as a function of distance and time taken by the piston to move through the chamber. Temperature is measured with the platinum Resistance Temperature Detector (RTD) mounted at the base of the chamber. About $10 \mathrm{~mL}$ of heavy oil sample was fed into the sample container and was pushed into the sensor. The system was heated (in the presence of Nitrogen gas) to increase temperature at the interval of $5{ }^{\circ} \mathrm{C}$ using the environment controlled oven (Alade et al., 2016c; Kumasaka et al., 2016).

The viscosity of water-in-bitumen emulsions were measured at $60{ }^{\circ} \mathrm{C}$ with a shear rate of $0.14 \mathrm{~s}^{-1}$ (spindle number SC434) using Brookfield DV-I viscometer equipped with a programmable temperature controller (Model 106, Brookfield AMETEK, Inc., Middleboro, MA - see Fig. 3b). For each measurement, $9.4 \mathrm{~mL}$ of emulsion sample was transferred from the microreactor into the sample chamber in the thermocontainer. The samples were left to equilibrate to the desired $T_{e}$. The equilibration time was typically between 1 and $3 \mathrm{~min}$. The viscometer was regularly calibrated with the appropriate standard fluids before use. The percentage error was typically in the range $\pm 0.2-1.4 \%$.

\subsection{Evaluation of specific energy for emulsification}

Since emulsification is essentially as a result of mixing, emulsification energy is considered as mixing energy supplied to the bitumen and water in the reactor. Thus, the specific emulsification energy $\left(\varepsilon_{v}\right)$ is the energy input per unit volume of the bitumen and water in the reactor. Thus, $\varepsilon_{v}$ is obtained as a product of mixing power $\left(P_{m}\right)$ of bitumen and water system and mixing time $\left(t_{m}\right)$ divided by volume $(V)$ of the fluid.

$$
\varepsilon_{v}=\frac{P_{m} t_{m}}{V}
$$

In addition, for a batch mixing process in an agitated vessel, at laminar regime, the mixing power $\left(P_{m}\right)$ is a function of bitumen viscosity $\left(\mu_{b}\right)$, mixing speed $\left(N_{i}\right)$ and diameter of the impeller $\left(D_{i}\right)$ as given in equation (4).

$$
P_{m}=P_{0} \mu_{b} N_{i}^{2} D_{i}^{3}
$$

The power number $\left(P_{0}\right)$ is a function of Reynolds number $\left(R_{e i}\right)$ and can be obtained using equations (5) (Foucault $e t$ 


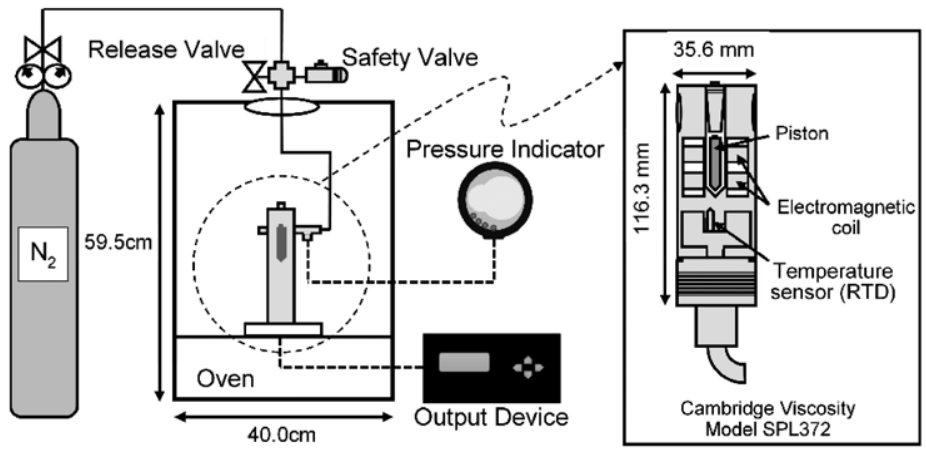

(a) Cambridge viscometer set-up

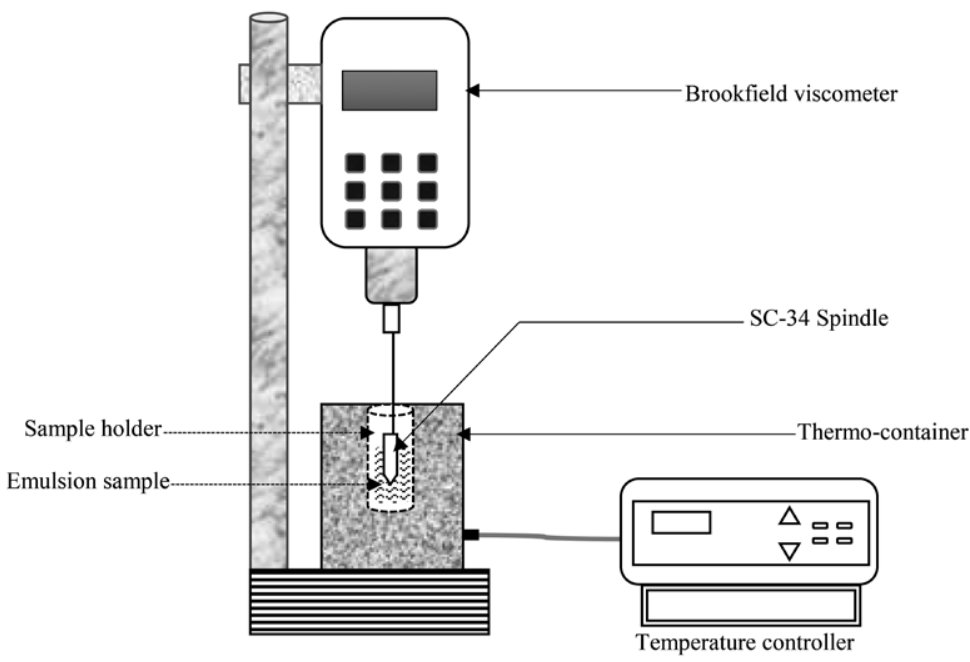

(b) Brookfield DV-I viscometer set-up

Fig. 3 Viscometers used in measurements

al., 2005) .

$$
P_{0}=f\left(R_{e i}\right)
$$

And considering non-Newtonian pseudoplastic fluid using an exponential model relating the apparent viscosity with the mixing speed $\left(N_{i}\right)$, shearing temperature $\left(T_{s}\right)$ of waterbitumen emulsion, and the fraction of bitumen $\left(C_{B}\right)$ present in the emulsion, Reynolds number, $R_{e i}$ can be obtained using equation (6).

$$
R_{e i}=\frac{N_{i} \rho\left(T_{b}\right) D_{i}^{2}}{V}
$$

The bitumen density $\left(\rho\left(T_{b}\right)\right)$ at a given temperature $\left(T_{b}\right)$, and density of bitumen, $\left(\rho\left(T_{r e f}\right)\right)$ at a reference temperature $\left(T_{\text {ref }}\right)$ is calculated as given in equation (7).

$$
\rho\left(T_{b}\right)=\rho\left(T_{r e f}\right) \cdot \exp \left[-\delta\left(T_{b}-T_{r e f}\right)\right]
$$

The apparent viscosity of bitumen is expressed by an exponential model as given in equation (8)

$$
\mu_{b}=A_{1} N_{i}^{A_{2}} \cdot \exp \left(\frac{\beta}{T_{s}}+\alpha C_{B}\right)
$$

where $A_{1}$ and $A_{2}, \beta$, and $\alpha$ are the viscosity dependent model parameters quantifying the effects of mixing speed $N_{i}$, shearing temperature $T_{s}$ and bitumen content $C_{B}$, respectively.

\section{Results and discussion}

\subsection{Effect of formation temperature and mixing speed on emulsification energy}

The specific energy of emulsification $\left(\varepsilon_{v}\right)$ decreased with increasing formation temperature $\left(T_{f}\right)$ and increased with increasing mixing speed $\left(N_{i}\right)$ as shown in Fig. 4 (symbol represents experimental data). For Oil C, the value of $\varepsilon_{v}$ decreased from $8.77 \mathrm{E} 8 \mathrm{kJm}^{-3}$ to $2.31 \mathrm{E} 6 \mathrm{kJm}^{-3}$ from the $T_{f}$ of $50{ }^{\circ} \mathrm{C}$ and $180{ }^{\circ} \mathrm{C}$, respectively, at the mixing speed $\left(N_{i}\right)$ $=11.7 \mathrm{~s}^{-1}$. In the case of Oil $\mathrm{N}$, at the mixing speed $N_{i}=$ $11.7 \mathrm{~s}^{-1}$ and the emulsion formation temperature $\left(T_{f}\right)$ of $50{ }^{\circ} \mathrm{C}, \varepsilon_{v}$ decreased from $5.78 \mathrm{E} 9 \mathrm{kJm}^{-3}$ to $4.44 \mathrm{E} 6 \mathrm{kJm}^{-3}$ at the $T_{f}$ of $180{ }^{\circ} \mathrm{C}$. In addition, for Oil C, increased in $N_{i}$ from $11.7 \mathrm{~s}^{-1}$ to $23.3 \mathrm{~s}^{-1}$ resulted into the increase in $\varepsilon_{v}$ to $2.19 \mathrm{E} 9$ $\mathrm{kJm}{ }^{-3}$ at $50{ }^{\circ} \mathrm{C}$, and $7.98 \mathrm{E} 6 \mathrm{kJm}^{-3}$ at $180{ }^{\circ} \mathrm{C}$. Similarly, the increased in mixing speed $\left(N_{i}\right)$ from $11.7 \mathrm{~s}^{-1}$ to 23.3 $\mathrm{s}^{-1} 1$ caused increase in the value of $\varepsilon_{v}$ to $1.99 \mathrm{E} 10 \mathrm{kJm}^{-3}$ and $1.54 \mathrm{E} 7 \mathrm{kJm}^{-3}$ at $50{ }^{\circ} \mathrm{C}$ and $180{ }^{\circ} \mathrm{C}$, respectively, for oil $\mathrm{N}$. These observations are due to the fact that viscosity of the fluids decreases with increasing temperature (see Fig. 5). It 
also indicates that the higher the temperature, the lower the resistant poses by the viscosity of the fluid to emulsification; and as a result of viscosity difference, emulsification energy was observed to be higher for the oil $\mathrm{N}$ compared to oil $\mathrm{C}$ at every temperature and mixing speed. Moreover, the specific emulsification energy $\left(\varepsilon_{v}\right)$ was correlated with emulsion formation temperature $\left(T_{f}\right)$ and mixing speed $\left(N_{i}\right)$ using the power law relationship, equation (9). The calculated values of specific emulsification energy are represented using lines in Fig. 4. Correlation parameters are presented in Table 3.

$$
\varepsilon_{v}=\varepsilon_{v o} T_{f}^{\phi} N_{i}^{\tau}
$$

where $\phi$ and $\tau$ are the system dependent model parameters quantifying the effect of formation temperature $\left(T_{f}\right)$ and mixing speed $\left(N_{i}\right)$, respectively.

3.2 Effects of formation temperature $\left(T_{f}\right)$, mixing speed $\left(N_{i}\right)$ and water content $\left(C_{W}\right)$ on the percentage emulsification $\left(r_{e}\right)$ and viscosity of emulsion.

The extent of dispersing water particles in the bitumen phase at the given formation temperature and mixing speed is defined as the percentage emulsification $\left(r_{e}\right)$. This is calculated as the percentage of water dispersed in the bitumen phase after the mixing time.
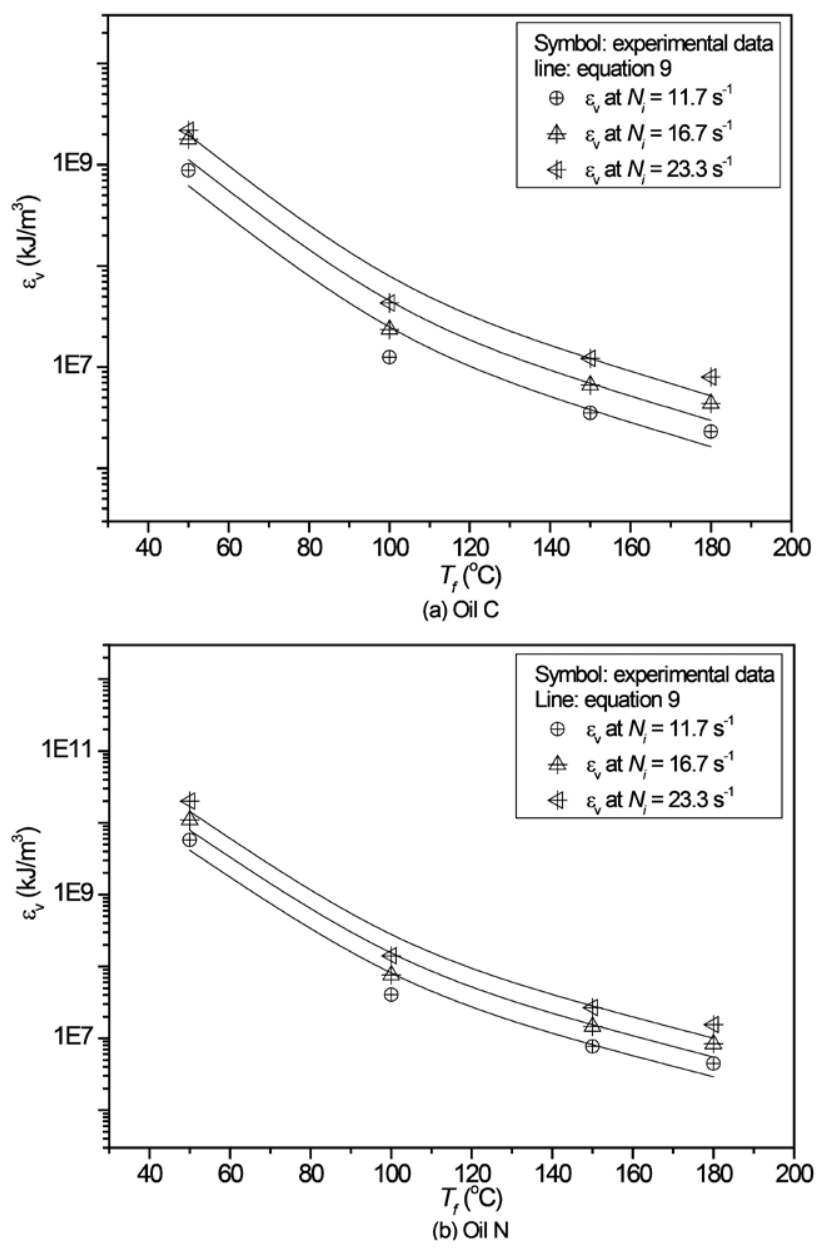

Fig. 4 Effect of emulsion formation temperature $\left(T_{f}\right)$ and mixing speed $\left(N_{i}\right)$ on the specific emulsification energy of Oils $\mathrm{C}$ and $\mathrm{N}$

$$
r_{e}=\frac{W_{d}}{W_{i}} \times 100
$$

Water dispersed in bitumen $\left(W_{d}\right)$ is given in equation (11).

$$
W_{d}=W_{i}-W_{f}
$$

Fig. 6 is the graph of percentage emulsification $\left(r_{e}\right)$ at different emulsion formation temperatures $\left(T_{f}\right)$ and mixing speed $\left(N_{i}\right)$, while the effect of water content $\left(C_{W}\right)$ on the percentage emulsification $\left(r_{e}\right)$ is shown in Fig. 7. It can be observed from Fig. 6 that at the mixing speed of $11.7 \mathrm{~s}^{-1}$, an increase in emulsion formation temperature from 50 to $100{ }^{\circ} \mathrm{C}$ caused the percentage dispersion of water into the bitumen (percentage emulsification) to increase from 30 to $61 \% \mathrm{w} /$ $\mathrm{w}$ for Oil N (asphaltene content of $24.8 \%$ ). However, at the formation temperatures of $150{ }^{\circ} \mathrm{C}$ and $180{ }^{\circ} \mathrm{C}$, mixing speed of $11.7 \mathrm{~s}^{-1}$, percentage emulsification decreased to $55 \% \mathrm{w} / \mathrm{w}$ and to $25 \% \mathrm{w} / \mathrm{w}$, respectively. In addition, at the mixing speed of $23.3 \mathrm{~s}^{-1}$, percentage emulsification increased to $39 \% \mathrm{w} / \mathrm{w}$ at formation temperature of $50{ }^{\circ} \mathrm{C}$ and at formation temperature of $100{ }^{\circ} \mathrm{C}$, percentage emulsification increased to $75 \% \mathrm{w} / \mathrm{w}$. This value decreased to $60 \% \mathrm{w} / \mathrm{w}$ and $38 \% \mathrm{w} / \mathrm{w}$ at formation temperature of $150{ }^{\circ} \mathrm{C}$ and $180{ }^{\circ} \mathrm{C}$, respectively. In comparison, it was observed, for Oil C (13.4\% asphaltene content), that the percentage emulsification at $11.7 \mathrm{~s}^{-1}$, increased from $44 \%$ $\mathrm{w} / \mathrm{w}$ to $72 \% \mathrm{w} / \mathrm{w}$, at the formation temperatures of $50{ }^{\circ} \mathrm{C}$ and $100{ }^{\circ} \mathrm{C}$, respectively. At the formation temperatures of $150{ }^{\circ} \mathrm{C}$ and $180{ }^{\circ} \mathrm{C}$, the value decreased to $33 \% \mathrm{w} / \mathrm{w}$ and $20 \% \mathrm{w} / \mathrm{w}$, respectively. At the mixing speed of $23.3 \mathrm{~s}^{-1}$ and formation temperature of $50{ }^{\circ} \mathrm{C}$, the percentage emulsification was 50

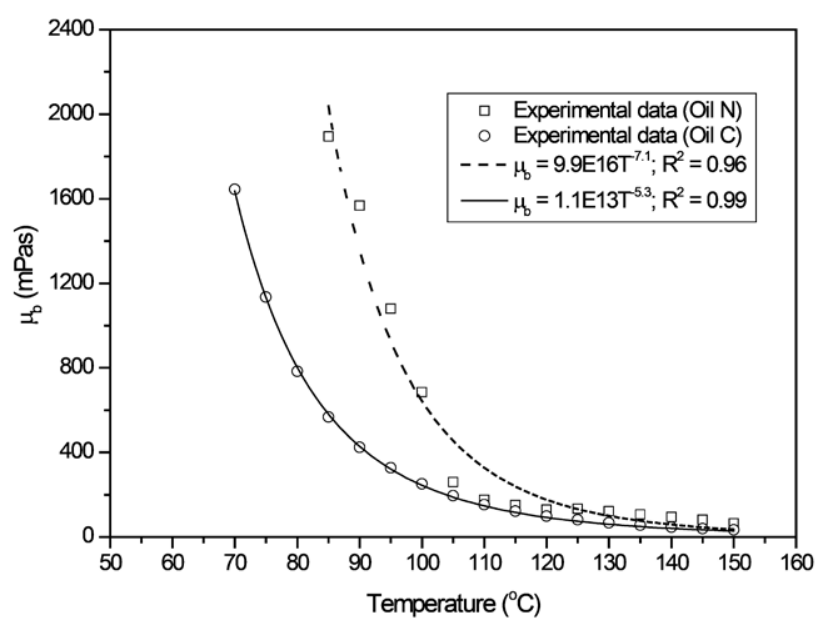

Fig. 5 Change in viscosity of bitumen samples with temperature

Table 3 Correlation parameters in equation 9 for Oil C and Oil N.

\begin{tabular}{l|ccccc}
\hline Bitumen sample & $\varepsilon_{v o}$ & $\phi$ & $\tau$ & $\mathrm{R}^{2}$ & $\mathrm{AAD}$ \\
\hline Oil C & $7.49 \mathrm{E}+14$ & -4.63 & 1.67 & 0.97 & 38.40 \\
\hline Oil N & $2.24 \mathrm{E}+17$ & -5.67 & 1.79 & 0.99 & 42.57 \\
\hline
\end{tabular}


$\% \mathrm{w} / \mathrm{w}$. This increased to $90 \% \mathrm{w} / \mathrm{w}$ at $100{ }^{\circ} \mathrm{C}$; and decreased to $45 \% \mathrm{w} / \mathrm{w}$ and $33 \% \mathrm{w} / \mathrm{w}$ at the formation temperatures of $150{ }^{\circ} \mathrm{C}$ and $180{ }^{\circ} \mathrm{C}$, respectively.

From the descriptions above, it can generally be deduced that between the formation temperatures of 50 and $100{ }^{\circ} \mathrm{C}$, there was an increase in the extent of emulsification for the two oil samples. However, the percentage emulsification decreased above $100{ }^{\circ} \mathrm{C}$ formation temperature. On the other hand, an increase in mixing speed resulted in increase in percentage emulsification at every temperature. In addition, Fig. 7 shows that the percentage emulsification decreased with increasing water content $\left(C_{W}=25-75 \% \mathrm{w} /\right.$ w). Furthermore, comparing the two oil samples, a more interesting behaviour of the system was observed below and above the formation temperature of $100{ }^{\circ} \mathrm{C}$. It was observed that the percentage emulsification was higher for Oil $\mathrm{C}$ at the formation temperature below $100{ }^{\circ} \mathrm{C}$, and above this temperature, percentage emulsification increased for the oil $\mathrm{N}$. The observation concerning the increase in percentage emulsification due to mixing speed is consistent with the response of emulsification energy which was described

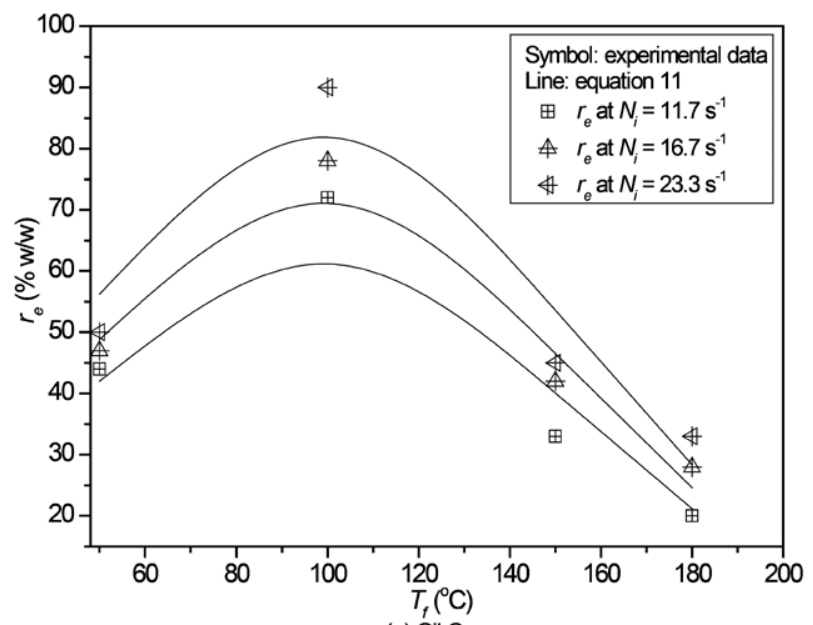

(a) Oil C

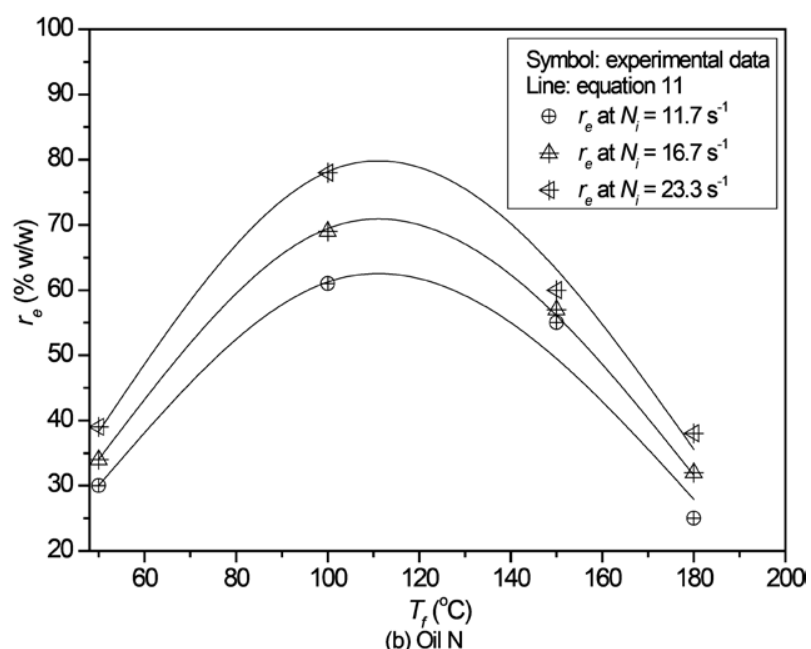

Fig. 6 Response of percentage bitumen emulsification $\left(r_{e}\right)$ to the formation temperature $\left(T_{f}\right)$ and mixing speed $\left(N_{i}\right)$ earlier. On the other hand, the response of the percentage emulsification to formation temperature could be corroborated considering the thermodynamics of the process. As presented earlier in Fig. 5, the viscosity of the continuous bitumen phase is very high at temperature below $100{ }^{\circ} \mathrm{C}$, hence the observed low emulsification. It had been reported that the viscosity of crude oil affects the extent of emulsification (Fingas, 2014; Wen et al., 2016). Interestingly however, above the formation temperature of $100{ }^{\circ} \mathrm{C}$, the viscosity was significantly decreased; and together with the increase in kinetic energy of the particles of water (particle coalescence and Ostwald ripening), the separation of water during mixing at this condition was accelerated. Hence, the decrease in percent emulsification. For the different behaviour observed in the two oil samples, plausible explanations can be linked with the properties of crude oil including density, viscosity, asphaltene, resin content, clay content etc. According to Fingas (2014) due to variation in the properties of crude oil, different types of water-in-oil emulsion named as meso-stable, stable emulsions, entrained water-in-oil and unstable emulsions can be formed.

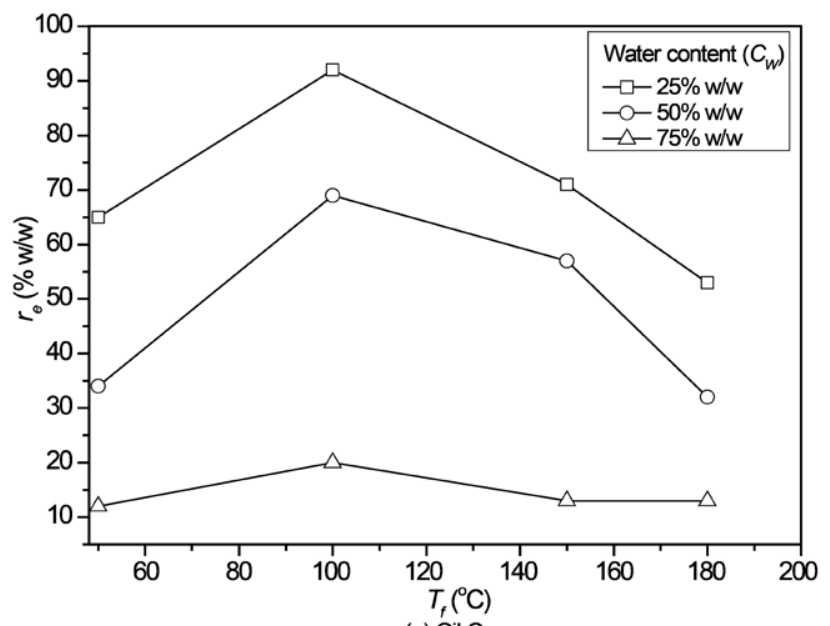

(a) Oil C

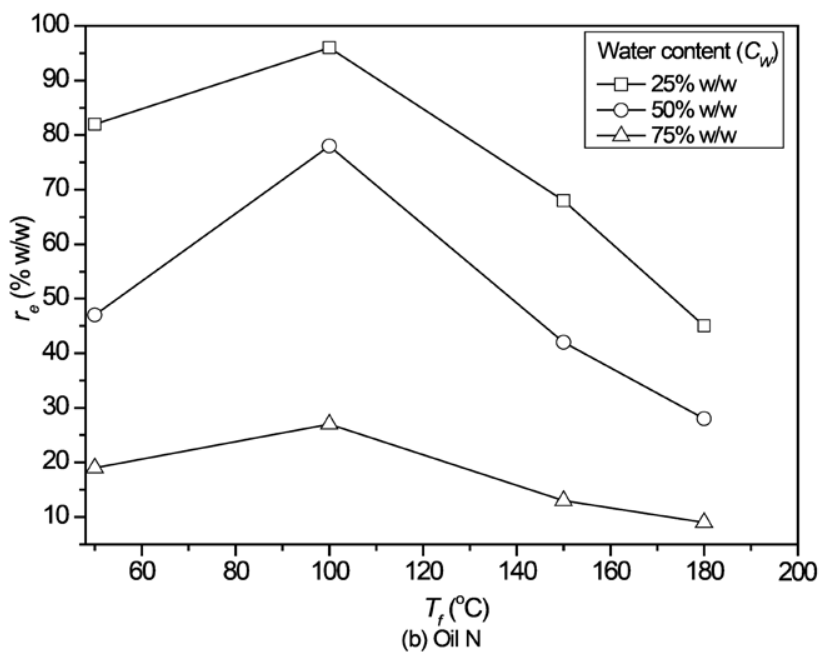

Fig. 7 Experimental values of the percentage bitumen emulsification $\left(r_{e}\right)$ vs formation temperature $\left(T_{f}\right)$ and water content $\left(C_{W}\right)$ 
Table 4 Correlation parameters in equation 12 for Oil C and Oil N.

\begin{tabular}{l|cccccc}
\hline Bitumen sample & $X_{1}$ & $X_{2}$ & $X_{3}$ & $\tau_{i}$ & $\mathrm{R}^{2}$ & $\mathrm{AAD}$ \\
\hline Oil C & 1.53 & 0.031 & -0.00016 & 0.42 & 0.92 & 11.44 \\
\hline Oil N & 0.90 & 0.042 & -0.00019 & 0.35 & 0.98 & 3.26 \\
\hline
\end{tabular}

Therefore, in the present investigation, it can be said that there are possibly different viscosity windows during which emulsification is favored within the two oil samples. And it is more convenient to state that emulsification become more pronounced in the Oil $\mathrm{C}$ at the formation temperature below $100{ }^{\circ} \mathrm{C}$ when its viscosity is higher than $244 \mathrm{mPas}$, while at $150{ }^{\circ} \mathrm{C}$ and $180{ }^{\circ} \mathrm{C}$, the viscosity became 28 and $10 \mathrm{mPas}$, respectively, which may be less favorable to stabilize water particles dispersed in the oil matrix. Similarly, in the case of Oil $\mathrm{N}$, at the temperatures of $50{ }^{\circ} \mathrm{C}$ and $100{ }^{\circ} \mathrm{C}$, the relatively high viscosity ( 88000 and $643 \mathrm{mPas}$ ) decreases the extent of emulsification due to inability of the water particle to penetrate and distribute within the bitumen matrix. However, at the higher temperatures $\left(150{ }^{\circ} \mathrm{C}\right.$ and $\left.180{ }^{\circ} \mathrm{C}\right)$, the viscosity $(65$ and $40 \mathrm{mPas}$, respectively) of the oil become more favorable for emulsification compared to Oil C.

The percentage emulsification $\left(r_{e}\right)$ at different emulsion formation temperature $\left(T_{f}\right)\left({ }^{\circ} \mathrm{C}\right)$ and mixing speed $\left(N_{i}\right)$ was correlated using equation (12). The calculated values (shown using lines) are compared with the experimental values (symbols) as presented in Fig. 6. Correlation parameters are presented in Table 4.

$$
r_{e}=\exp \left(X_{1}+X_{2} T_{f}+X_{3} T_{f}^{2}\right) \cdot N_{i}^{\tau i}
$$

Furthermore, the relationship between the percentage water content of emulsion $\left(C_{t}\right)$, given in equation (13), and the apparent viscosity of water-in-bitumen emulsion $\left(\mu_{e}\right)$ measured at $60{ }^{\circ} \mathrm{C}$ and shearing rate of $0.14 \mathrm{~s}^{-1}$ is presented in Fig. 8. $C_{t}$ is defined as the weight percent of the water dispersed in bitumen over total weight of emulsion.

$$
C_{\tau}=\frac{W_{d}}{W_{d}+W_{b}} \times 100
$$

As expected, Fig. 8 shows that water-in-bitumen emulsions produced have higher viscosity compared to the original bitumen.

\subsection{Effect of formation temperature and mixing speed on the particle size of emulsion}

Particle size of emulsion (and its distribution) is a crucial factor determining its characteristics. This affects the stability and viscosity; and ultimately assists in design and simulation of separation system. The average particle size of emulsions and its distribution according to the variation in formation temperature and mixing speed are presented in Fig. 9 and 10. It was generally observed that the particle size decreases with the increase in both formation temperature and the mixing speed. From Fig. 9, in the case of Oil C, at
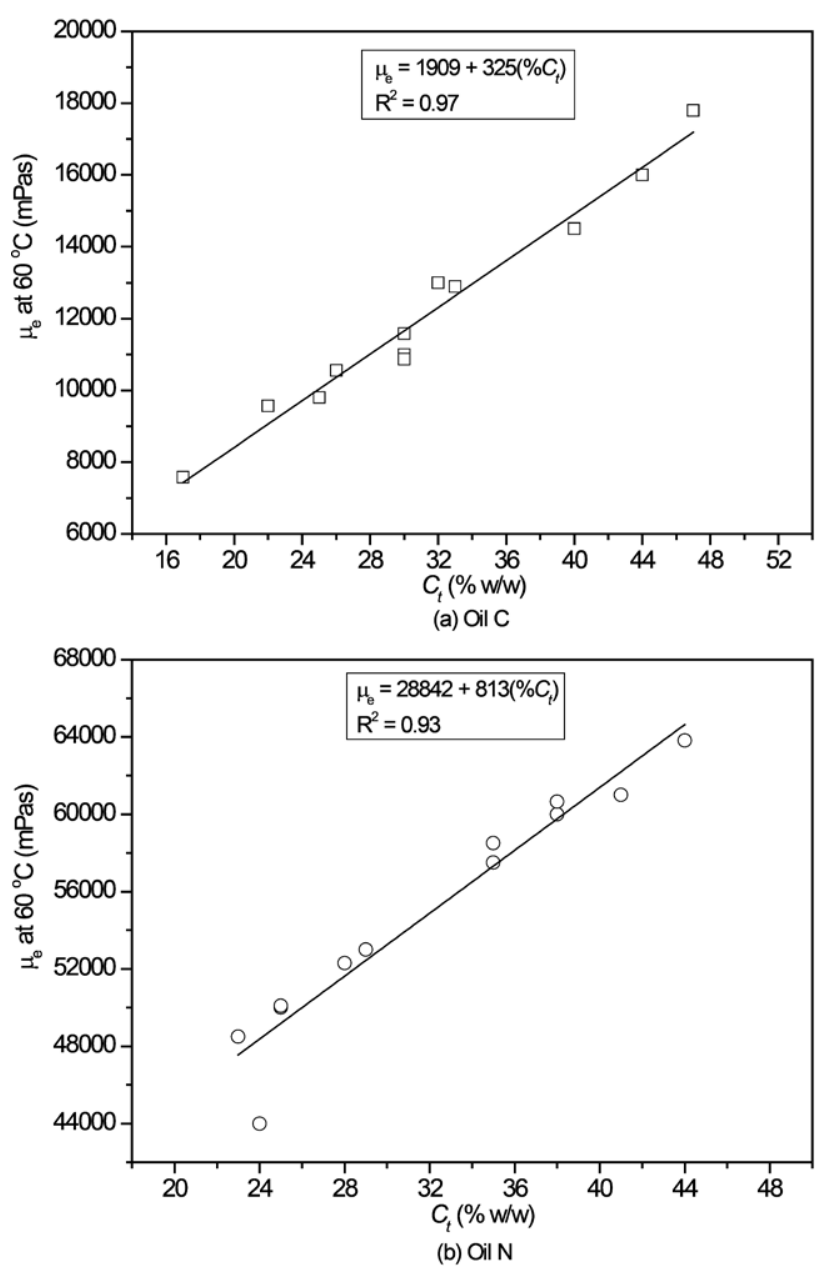

Fig. 8 Apparent viscosity of emulsion $\left(\mu_{e}\right)$ vs water content $\left(C_{t}\right)$

the formation temperature of $50{ }^{\circ} \mathrm{C}$ and mixing speed of $11.7 \mathrm{~s}^{-1}$, the particle size was $44.5 \mu \mathrm{m}$. This decreased to $16.9 \mu \mathrm{m}$ at the mixing speed of $23.3 \mathrm{~s}^{-1}$. At the formation temperature of $180{ }^{\circ} \mathrm{C}$ and mixing speed of $11.7 \mathrm{~s}^{-1}$, the particle size was $6.1 \mu \mathrm{m}$ and decreased to $4.5 \mu \mathrm{m}$ at $23.3 \mathrm{~s}^{-1}$. For Oil N, from Fig. 10, at the emulsion formation temperature of $50{ }^{\circ} \mathrm{C}$, the particle size decreased from $35 \mu \mathrm{m}$ at the mixing speed of $11.7 \mathrm{~s}^{-1}$ to $16.6 \mu \mathrm{m}$ at the mixing speed of 23.3 $\mathrm{s}^{-1}$. At formation temperature of $180{ }^{\circ} \mathrm{C}$, the particle size decreased from $9.7 \mu \mathrm{m}$ at the mixing speed of $11.7 \mathrm{~s}^{-1}$, to 5.5 $\mu \mathrm{m}$ at the mixing speed of $23.3 \mathrm{~s}^{-1}$. The observed smaller particle size of emulsions at higher temperatures is due to the fact that emulsification at the higher temperature above $100{ }^{\circ} \mathrm{C}$ occurs under high turbulent mixing environment (due to increase in saturation pressures - see Fig. 11) which brakes the particle further. The photomicrographic images of the emulsions are presented in Fig. 12 and 13.

Moreover, the average particle size is correlated with the formation temperature and the mixing speed using an exponential relationship, equation (14). The agreement between the experimental and calculated particle size is presented in Fig. 13. Table 5 presents the correlation parameters. 


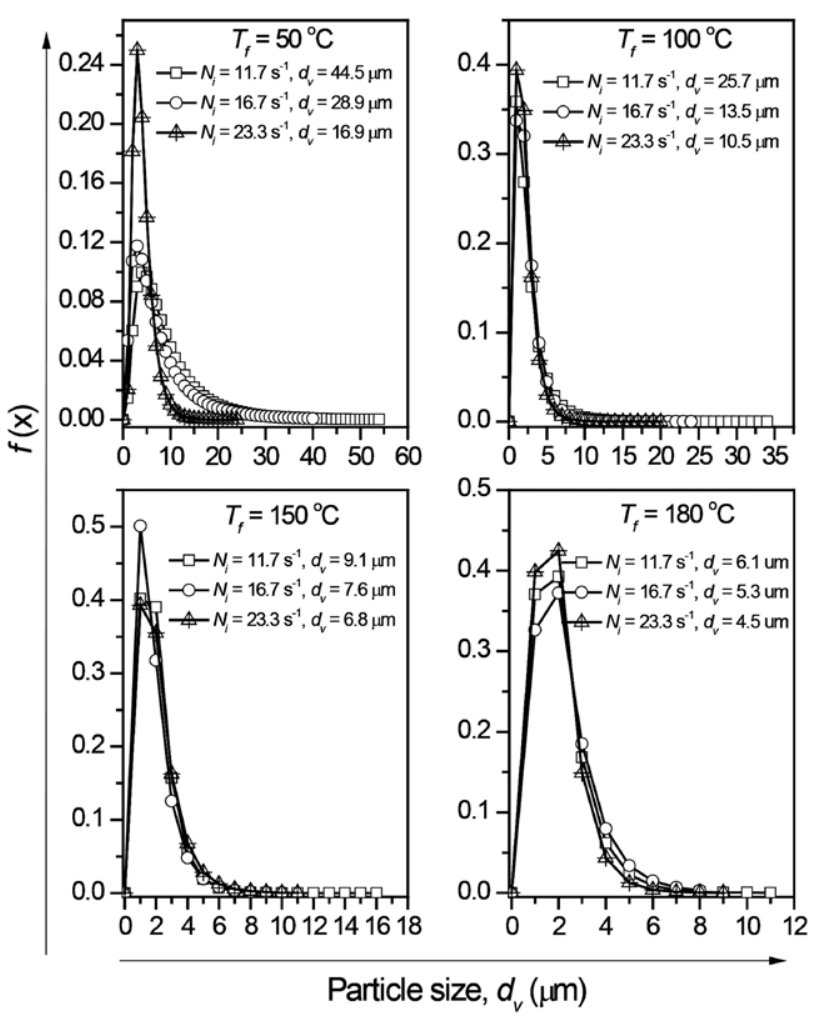

Fig. 9 Average particle size and particle size distribution of water-in-bitumen emulsion (Oil C)

Table 5 Correlation parameters in equation 14 for Oil C and Oil N.

\begin{tabular}{l|ccccl}
\hline Bitumen sample & $d_{v o}$ & $\Theta$ & $\delta$ & $\mathrm{R}^{2}$ & $\mathrm{AAD}$ \\
\hline Oil C & 1.54 & 105.2 & 14.3 & 0.89 & 21.5 \\
Oil N & 2.43 & 78.6 & 13.0 & 0.95 & 9.8 \\
\hline
\end{tabular}

$$
d_{v}=d_{v o} \cdot \exp \left(\frac{\Theta}{T_{f}}+\frac{\delta}{N_{i}}\right)
$$

\section{Conclusion}

The following conclusions can be drawn from the investigation:

1. The specific emulsification energy $\left(\varepsilon_{v}\right)$ decreases as the emulsion formation temperature, $T_{f}$ increases and increases with the mixing speed. For Oil N, at mixing speed $N_{i}=11.7 \mathrm{~s}^{-1}, \varepsilon_{v}$ decreased from $5.78 \mathrm{E} 9$ $\mathrm{kJm}^{-3}$ to $4.44 \mathrm{E} 6 \mathrm{kJm}^{-3}$ as the emulsion formation temperature $\left(T_{f}\right)$ increased from $50{ }^{\circ} \mathrm{C}$ to 180 ${ }^{\circ} \mathrm{C}$, while at the mixing speed of $23.3 \mathrm{~s}^{-1}$, the specific emulsification energy $\left(\varepsilon_{v}\right)$ decreased from $2.10 \mathrm{E} 10$ $\mathrm{kJm}^{-3}$ at emulsion formation temperature of $50{ }^{\circ} \mathrm{C}$ to $1.54 \mathrm{E} 7 \mathrm{kJm}^{-3}$ at $180{ }^{\circ} \mathrm{C}$. Similarly, for Oil C, at mixing speed of $11.7 \mathrm{~s}^{-1}$, the specific emulsification energy

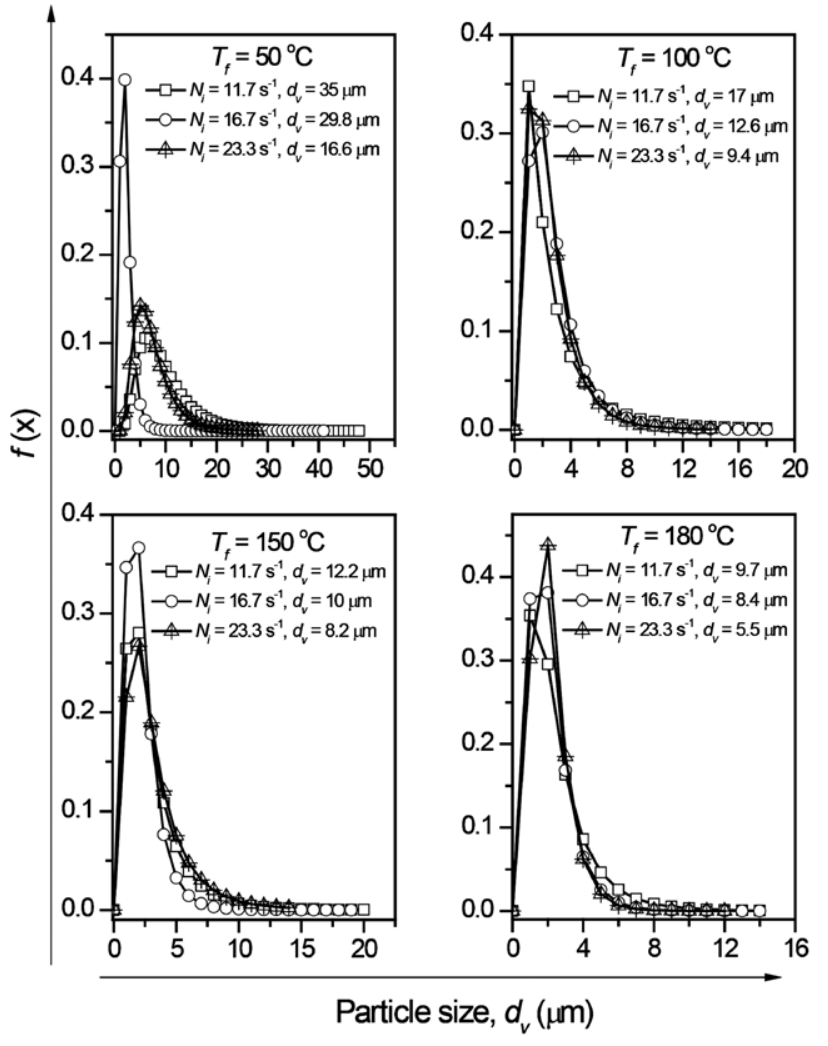

Fig. 10 Average particle size and particle size distribution of water-in-bitumen emulsion (Oil N)

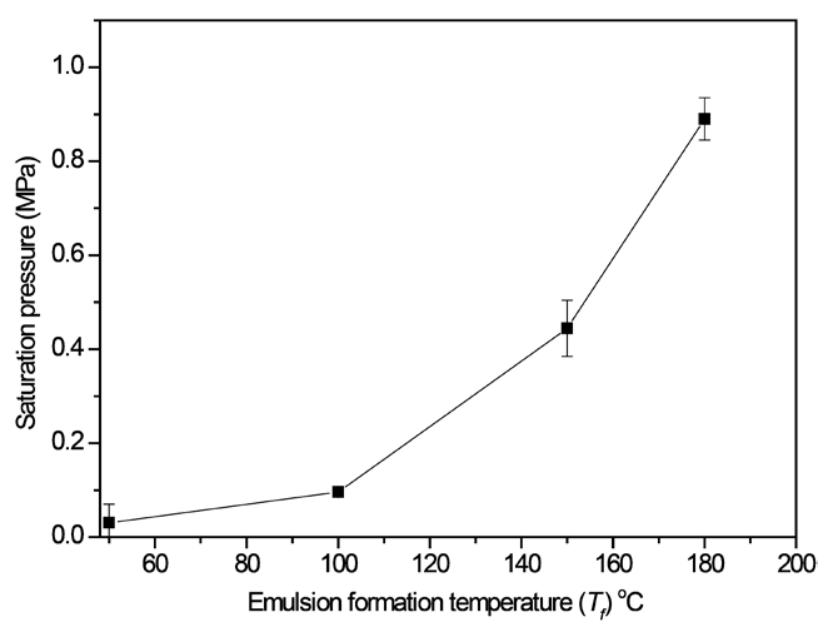

Fig. 11 Saturation pressure in the reactor during emulsification vs formation temperature $\left(T_{f}\right)$

$\left(\varepsilon_{v}\right)$ decreased from $8.77 \mathrm{E} 8 \mathrm{kJm}^{-3}$ to $2.31 \mathrm{E} 6 \mathrm{kJm}^{-3}$ as the emulsion formation temperature increased from 50 ${ }^{\circ} \mathrm{C}$ to $180{ }^{\circ} \mathrm{C}$. And at the mixing speed $N_{i}=23.3 \mathrm{~s}^{-1}$, the specific emulsification energy $\left(\varepsilon_{v}\right)$ decreased from $2.19 \mathrm{E} 9 \mathrm{kJm}^{-3}$ at emulsion formation of $50{ }^{\circ} \mathrm{C}$ to $7.98 \mathrm{E} 6$ $\mathrm{kJm}^{-3}$ at emulsion formation of $180{ }^{\circ} \mathrm{C}$.

2. The extent of emulsification $\left(\varepsilon_{f}\right)$ i.e. percentage bitumen emulsified (water dispersed in the bitumen phase) is affected by the emulsion formation temperature and 


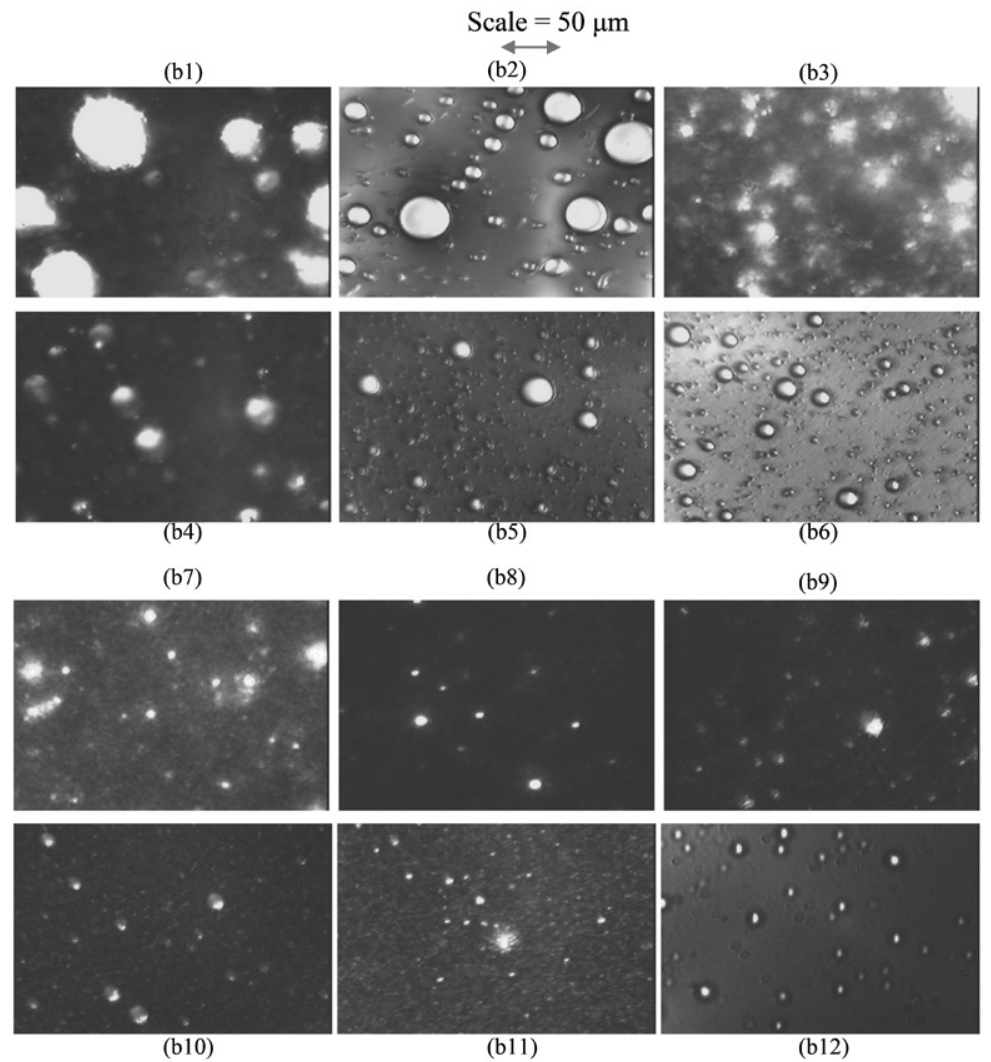

Fig. 12 Particles photomicrographs from emulsions using Oil C: $\mathrm{b}_{1}-\mathrm{b}_{3}\left(T_{f}=50^{\circ} \mathrm{C}\right.$ and $\left.N_{i}=11.7-23.3 \mathrm{~s}^{-1}\right), \mathrm{b}_{4}-\mathrm{b}_{6}\left(T_{f}=\right.$ $100{ }^{\circ} \mathrm{C}$ and $\left.N_{i}=11.7-23.3 \mathrm{~s}^{-1}\right), \mathrm{b}_{7}-\mathrm{b}_{9}\left(T_{f}=150{ }^{\circ} \mathrm{C}\right.$ and $\left.N_{i}=11.7-23.3 \mathrm{~s}^{-1}\right)$ and $\mathrm{b}_{10}-\mathrm{b}_{12}\left(T_{f}=180{ }^{\circ} \mathrm{C}\right.$ and $N_{i}=$ $\left.11.7-23.3 \mathrm{~s}^{-1}\right)$

(a1) Scale $=50 \mu \mathrm{m}$

(a2) (a3)

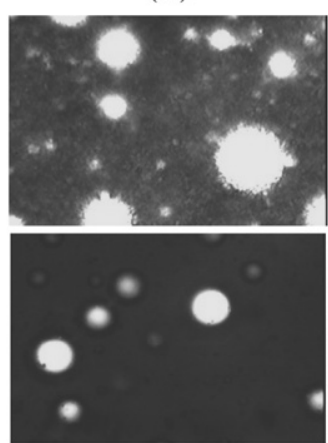

(a4)

(a7)
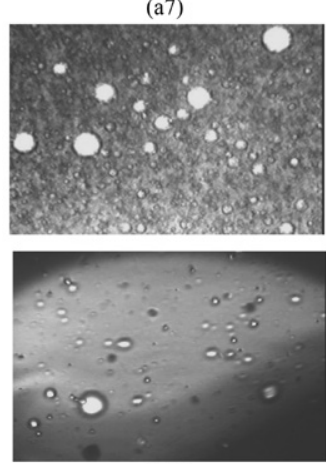

(a10)

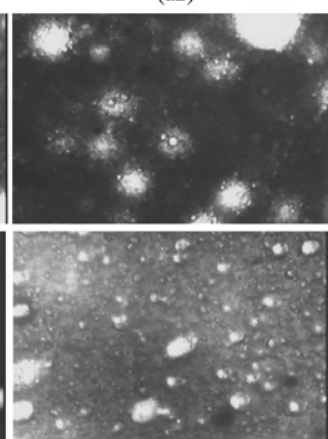

(a5)

(a8)
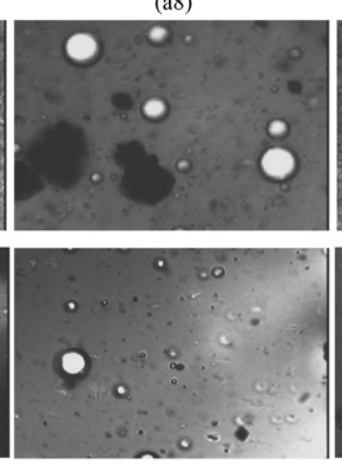

(a11)

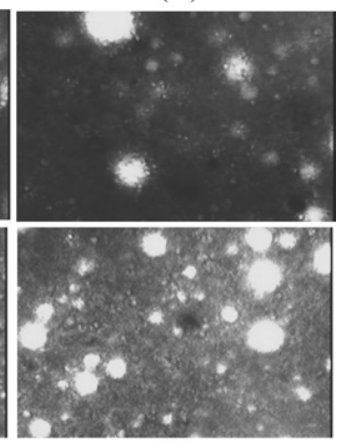

(a6)

(a9)
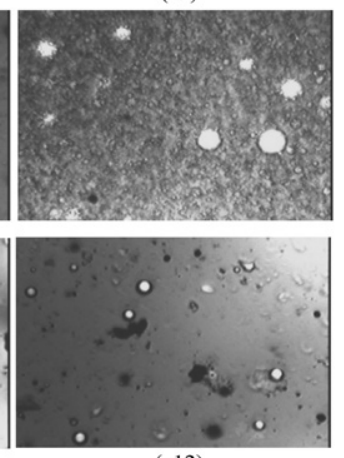

(a12)

Fig. 13 Particles photomicrographs from emulsions using Oil $\mathrm{N}: \mathrm{a}_{1}-\mathrm{a}_{3}\left(T_{f}=50{ }^{\circ} \mathrm{C}\right.$ and $\left.N_{i}=11.7-23.3 \mathrm{~s}^{-1}\right), \mathrm{a}_{4}-\mathrm{a}_{6}\left(T_{f}=\right.$ $100{ }^{\circ} \mathrm{C}$ and $\left.N_{i}=11.7-23.3 \mathrm{~s}^{-1}\right), \mathrm{a}_{7}-\mathrm{a}_{9}\left(T_{f}=150{ }^{\circ} \mathrm{C}\right.$ and $\left.N_{i}=11.7-23.3 \mathrm{~s}^{-1}\right)$ and $\mathrm{a}_{10}-\mathrm{a}_{12}\left(T_{f}=180{ }^{\circ} \mathrm{C}\right.$ and $N_{i}=$ $\left.11.7-23.3 \mathrm{~s}^{-1}\right)$ 


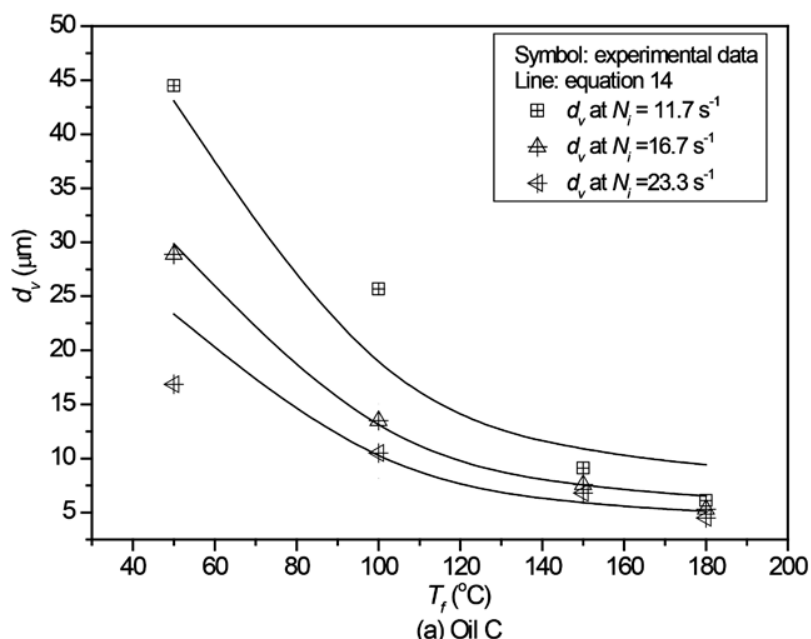

(a) Oil C

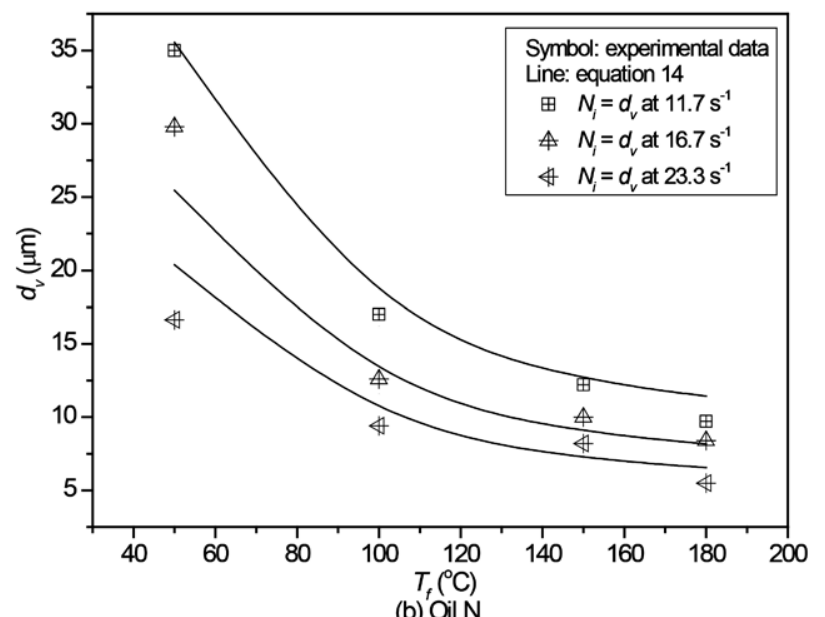

Fig. 14 Change in emulsion particle size $\left(d_{v}\right)$ with formation temperature $\left(T_{f}\right)$ and mixing speed, $\left(N_{i}\right)$

the mixing speed. Percentage emulsification initially increased with the formation temperature (from 50 $-100{ }^{\circ} \mathrm{C}$ ) and decreased with formation temperature thereafter. For Oil N, mixing speed of $11.7 \mathrm{~s}^{-1}$, an increase in emulsion formation temperature from 50 ${ }^{\circ} \mathrm{C}$ to $100{ }^{\circ} \mathrm{C}$ caused the percentage emulsification to increase from $30 \% \mathrm{w} / \mathrm{w}$ to $61 \% \mathrm{w} / \mathrm{w}$ while a the formation temperatures of $150{ }^{\circ} \mathrm{C}$ and $180{ }^{\circ} \mathrm{C}$, percentage emulsification decreased to $55 \% \mathrm{w} / \mathrm{w}$ and to $25 \% \mathrm{w} / \mathrm{w}$, respectively. In comparison, for Oil $\mathrm{C}$, the percentage emulsification at $11.7 \mathrm{~s}^{-1}$, increased from $44 \% \mathrm{w} / \mathrm{w}$ to 72 $\% \mathrm{w} / \mathrm{w}$, at the formation temperatures of $50{ }^{\circ} \mathrm{C}$ and 100 ${ }^{\circ} \mathrm{C}$, respectively; and decreased to $33 \% \mathrm{w} / \mathrm{w}$ and $20 \% \mathrm{w} /$ $\mathrm{w}$, at the formation temperatures of $150{ }^{\circ} \mathrm{C}$ and $180{ }^{\circ} \mathrm{C}$, respectively.

3. The particle size of water dispersed in the bitumen phase decreased with an increase of formation temperature and mixing speed. In other words, the particle size decreased with increasing emulsification energy. For Oil N, increase in mixing speed from 11.7 to $23.3 \mathrm{~s}^{-1}$ decreased the particle size from $35 \mu \mathrm{m}$ to $16.6 \mu \mathrm{m}$, at the emulsion formation temperature of $50{ }^{\circ} \mathrm{C}$. At the formation temperature of $180{ }^{\circ} \mathrm{C}$, the particle size decreased from 9.7 to $5.5 \mu \mathrm{m}$ as the mixing speed increased from 11.7 to $23.3 \mathrm{~s}^{-1}$. For Oil $\mathrm{C}$, increase in mixing speed from 11.7 to $23.3 \mathrm{~s}^{-1}$ decreased the particle size from $44.5 \mu \mathrm{m}$ to $16.9 \mu \mathrm{m}$, at the emulsion formation temperature of 50 ${ }^{\circ} \mathrm{C}$. At the formation temperature of $180{ }^{\circ} \mathrm{C}$, the particle size decreased from 6.1 to $4.5 \mu \mathrm{m}$ as the mixing speed increased from 11.7 to $23.3 \mathrm{~s}^{-1}$, respectively.

4. Moreover, correlations have been developed to predict the effects of the process conditions on the emulsion properties viz. percentage emulsification and particle size.

\section{Acknowledgements}

Donation of bitumen sample by Japan Canada Oil Sands Limited (JACOS) is highly appreciated. I am also grateful to the TETFund/Obafemi Awolowo University, Nigeria, the Society of Petroleum Engineers (SPE Star Fellowship 2013), and the REPs Laboratory, Kyushu University, Japan for financial supports.

\section{List of symbols and abbreviation}

$C_{B} \quad:$ Bitumen content $(\% \mathrm{w} / \mathrm{w})$

$C_{W} \quad:$ Water content $(\% \mathrm{w} / \mathrm{w})$

$C_{t} \quad$ : Percentage water content of emulsion $(\% \mathrm{w} / \mathrm{w})$

$D_{i} \quad$ : Impeller diameter (m)

$d_{i} \quad:$ ith diameter of droplet $(\mu \mathrm{m})$

$d_{v} \quad$ : Particle size (diameter) of water dispersed in bitumen $(\mu \mathrm{m})$

$d_{v o} \quad: \begin{aligned} & \text { Pre-exponential factor of particle diameter } \\ & (\mu \mathrm{m})\end{aligned}$

$d_{v o} \quad: \begin{aligned} & \text { Pre-exponential factor of particle diameter } \\ & (\mu \mathrm{m})\end{aligned}$

$\varepsilon_{v} \quad:$ Specific emulsification energy $\left(\mathrm{kJ} / \mathrm{m}^{3}\right)$

: Temperature independent pre-exponential factor $\left(\mathrm{kJ} / \mathrm{m}^{3}\right)$

$r_{e} \quad:$ Percentage emulsify $(\% \mathrm{w} / \mathrm{w})$

$N_{i} \quad$ : Mixing speed $\left(\mathrm{s}^{-1}\right)$

$n_{i} \quad:$ Number of the droplets

$P_{m} \quad$ : Mixing power $(\mathrm{kJ} / \mathrm{s})$

$P_{0} \quad$ : Power number

$R_{e i} \quad:$ Reynolds number

$t_{m} \quad$ : Mixing time (s)

$T_{b} \quad$ : Bitumen temperature $\left({ }^{\circ} \mathrm{C}\right)$

$T_{\text {ref }} \quad$ : Bitumen reference temperature $\left({ }^{\circ} \mathrm{C}\right)$

$T_{s} \quad$ : Emulsion shearing temperature $\left({ }^{\circ} \mathrm{C}\right)$

$T_{f} \quad:$ Emulsion formation temperature $\left({ }^{\circ} \mathrm{C}\right)$

$V \quad$ : Volume $\left(\mathrm{m}^{3}\right)$

$W_{b} \quad$ : Weight of bitumen (g)

$W_{d} \quad:$ Water dispersed in bitumen $(\mathrm{g})$

$W_{f} \quad$ : Free water not dispersed into the bitumen $(\mathrm{g})$

$W_{i} \quad$ : Initial water content feed into the reactor $(\mathrm{g})$

$X_{1}, X_{2}, X_{3}$ : Formation temperature dependent model parameter

$\rho\left(T_{b}\right) \quad$ : Density of bitumen $\left(\mathrm{kg} / \mathrm{m}^{3}\right)$ at temperature $T_{b}$

$\rho\left(T_{\text {ref }}\right) \quad$ : Density of bitumen $\left(\mathrm{kg} / \mathrm{m}^{3}\right)$ at reference temperature $T_{\text {ref }}$

$\mu_{b} \quad$ : Viscosity of bitumen (mPas) 
$A_{1}, A_{2}, \beta, \alpha$ : Viscosity dependent model parameter

$\phi, \tau \quad:$ System dependent model parameter

$\mu_{e} \quad$ : Viscosity of emulsion (mPas)

$\delta, \Theta \quad$ : Constants (depend on the system)

$\beta, \alpha \quad$ : Viscosity dependent model parameters

$\mathrm{AAD} \quad$ : Percentage Average Absolute Deviation

TEOR : Thermal Enhanced Oil Recovery

C : Canadian bitumen

$\mathrm{N} \quad$ : Nigerian bitumen

\section{References}

Al-Bahlani, M. and Babadagli, T., 2009 : SAGD laboratory experimental and numerical simulation Studies: Areview of current status and future issues. Journal of Petrol Science and Engineering, 68, 135-150.

Alade, O. S., Sasaki, K., Sugai, Y., Ademodi, B., Kumasaka, J. and Nakano, M., 2016a : An aspect of bitumen emulsification by steam condensation: effect of formation temperature and bitumen content. Energy Source, Part A, 38, 1790- 1797.

Alade, O. S., Sasaki, K., Ogunlaja, A. S., Sugai, Y., B. Ademodi, Kumasaka, J., Ueda, R. and Nakano, M., 2016b : Thermal tolerance and Compatibility of NaOH-Poly (vinyl alcohol) in Bitumen Emulsification for Improved Flow properties. Energy Fuels, doi:10.1021/acs.energyfuels.6b02060.

Alade, O. S., Ademodi, B., Sasaki, K., Sugai, Y., Kumasaka, J., Ogunlaja, A.S., 2016c: Development of models to predict the viscosity of a compressed Nigerian bitumen and rheological property of its emulsions. Journal of Petroleum Science and Engineering, 141, 711-722.

Antes, F.G., Diehl, L.O., Pereira, J.S.F., Guimarães, R.C.L., Guarnieri, R.A., Ferreira, B.M.S., Dressler, V.L. and Flores, E.M.M., 2015 : Feasibility of low frequency ultrasound for water removal from crude oil emulsions. Ultrasonics Sonochemistry, 25, 70-75.

Badolato, G.G., Aguilar, F., Schuchmann, H.P., Sobisch, T. and Lerche, D., 2008 : Evaluation of long termstability of model emulsions by multisample analytical Centrifugation. Progress in Colloidal and Polymer Science, 134, 66-73.

Bennion, D.B., Chan, M., Sarioglu, G., Courtnage, D., Wansleeben, J. and Hirata,T.,1993 : The in situ formation of bitumen-water stable emulsions in porous media during thermal stimulation. SPE international Thermal Operations Symposium (Bakersfield, California), SPE25802-MS.

Clausse, D., Gomez, F., Dalmazzone, C. and Noik, C., 2005: A method for the characterization of emulsions, thermosgranulometry: application to water-in-crude oil emulsion. Journal of Colloid and Interface Science, 287, 694-703.

Chung, K.H. and Butler, R.M., 1987 : Geometrical effect of steam injection on the formation of emulsions in the Steam-Assisted Gravity Drainage Process, $38^{\text {th }}$ CIM Annual Technical Meeting (Calgary), Paper 87-38-22.

Chung, K.H. and Butler, R.M., 1989 : In situ emulsification by the condensation of steam in contact with bitumen. JCPT, 28 (1), PETSOC-89-01-04.

Fingas, M. F., 2014 : Water-in-oil emulsions: formation and prediction. Journal of Petroleum Science Research, 3(1), 38-49.

Foucault, S., Ascanio, G. and Tanguy, A.P., 2005 : Power characteristics in coaxial mixing: Newtonian and NonNewtonian fluids. Industrial Engineering and Chemical Research, 44, 5036-5043.

Fradette L., Brocart, B. and Tanguy, P. A., 2007: Comparison of mixing technologies for the production of concentrated emulsions. Chemical Engineering Research and Design, 85, 1553-1560.

Gingras, J., Tanguy, P. A., Mariotti, S. and Chaverot, P., 2005 : Effect of process parameters on bitumen emulsions. Chemical Engineering and Processing, 44, 979-986.

Hasan, S.W., Ghannam, T.M. and Esmail, N., 2010 : Heavy crude oil viscosity reduction and rheology or pipeline transportation. Fuel, 89, 1095-1100.

Kato K., Endo, K., Nakagawa, H. and Nakamura, T., 2013 : Development approaches and evaluations on oil sands reservoir. Journal of Japanese Association for Petroleum Technology, 78 (6) , 500-505.

Kumasaka, J., Sasaki, K., Sugai, Y., Alade, O.S. and Nakano, M., 2016 : Measurement of viscosity alteration for emulsion and umerical simulation on bitumen production by SAGD considering in situ emulsification. Journal of Earth Science and Engineering, 6, 10-17.

Martínez-Palou, R., María de Lourdes, M, Zapata-Rendón B., Mar-Juárez,E., Bernal- Huicochea, C., Juan de la Cruz C. and Jorge, A., 2011 : Transportation of heavy and extra heavy crude oil by pipeline: a review. Journal of Petroleum Science and Engineering, 75, 274-282

Mohammadzadeh, O. and Chatzis, I., 2010 : Pore-level investigation of heavy oil recovery using steam assisted gravity drainage (SAGD). Oil \& Gas Science and Technology - Rev IFP Energies nouvelles, 65 (6) , 839-857. DOI: $10.2516 /$ ogst/2010010.

Moradi, M., Alvarado, V. and Huzurbazar, S., 2011 : Effect of salinity on water-in-crude oil emulsions: evaluate on through drop-size distribution proxy. Energy Fuels, 25, 260-268.

Sasaki, K., Akibayashi, S., Yazawa, N., Doan, Q.T. and Farouq Ali, S.M., 2001 : Experimental modeling of the SAGD process -enhancing SAGD performance with periodic stimulation of the horizontal producer. SPE Journal, 6 (1) , 89-97.

Sasaki, K., Akibayashi, S., Yazawa, N. and Kaneko, F., 2002 : Microscopic visualization with high resolution optical-fiber scope at steam chamber interface on initial stage of SAGD process. SPE/DOE Improved Oil Recovery Symposium (Tulsa, USA), SPE-75241-MS.

Short, J.W., 2013 : Susceptibility of diluted bitumen products from the Alberta tar sands to sinking in water. JWS Consulting LLC 19315 Glacier Highway Juneau, Alaska 
99891 USA. Retrieved April, 2016 from https://docs.nebone.gc.ca/11-.

Takahasi, A. and Ogino, K., 2005 : Canada: a petroleum superpower with oil sands as conventional resources. Journal of Japanese Association for Petroleum Technology, $70(2), 157-163$

Wada, Y., 2006 : Oil sands development in Canada with the SAGD technology-Past, Present and future. Journal of Japanese Association for Petroleum Technology, 71 (2), 186-194.

Wen, J., Zhang, J., Wang, Z. and Zhang, Y. 2016 : Correlations between emulsification behaviors of crude oil-water systems and crude oil compositions. Journal of Petroleum Science and Engineering, 146, 1-9.

Wong, S.F., Lim, J.S. and Dol, S.S., 2015 : Crude oil emulsion: A review on formation, classification and stability of water-in-oil emulsions. Journal of Petroleum Science and Engineering, 135, 498-504.

Yamazaki, T., Roces, A.S., Kaneko, M., Ng, K. and Naito, K., 1994: The effects of solvents in conjunction with steam on the in situ recovery of bitumen from oil sands. Journal of Japanese Association for Petroleum Technology, 59 (3), 216-226.

\section{油中水滴型ビチュメンエマルションにおける エマルション生成プロセスの影響}

$$
\begin{array}{r}
\text { オラレカン アラデ・佐々木 } \\
\text { 久郎 } \\
\text { 菅井 裕一・アデモディ バヨ } \\
\text { 熊坂 純平・上田 良 }
\end{array}
$$

オイルサンドなどのビチュメン貯留層への水蒸気圧入な ぞによって生成される油中水滴型エマルションの粘度など の物理特性は, 生成後の水分含有量やその時点でのエマル ション温度に注目した研究が多くなされてきたが, エマル ション生成時の温度や擋汼混合（せん断）速度あるいは生 成時のエネルギーなどの生成プロセス条件の影響を評価し た研究は見当たらない。本研究では, ナイジェリア産と カナダ産のビチュメン油試料を使用し, 生成温度範囲 (50 〜 $180^{\circ} \mathrm{C}$ ) およびマイクロ反応器内の擋挥混合速度範囲 $\left(11.7 \sim 23.3 \mathrm{~s}^{-1}\right)$ においてビチュメン相に水滴を分散させ， エマルションの粘度, 水滴の粒子サイズおよびエマルショ ン化率（ビチュメン相中の水滴の分散程度）などのエマル ション特性に対する生成プロセス条件の影響評価を実験に よって測定し, 最終的に従来提案されている粘度の予測式 に対して, ビチュメンのエマルション化率や水滴の粒径分 布に影響を与える生成温度およびせん断速度条件を考慮し た修正式を新たに提示した。 